\title{
Exploring the Limits of $\pi$-Acid Catalysis Using Strongly Electrophilic Main Group Metal Complexes: the case of Zinc and
} Aluminum

\begin{abstract}
The catalytic activity of cationic NHC-Zn(II) and NHC$\mathrm{Al}(\mathrm{III})$ complexes in reactions that require the electrophilic activation of soft C-C $\pi$ bonds has been studied. The former proved able to act as a soft $\pi$-Lewis acid in a variety of transformations. The benefit of the bulky IPr NHC ligand was demonstrated by comparison with simple $\mathrm{ZnX}_{2}$ salts. The tested $\mathrm{NHC}-\mathrm{Al}(\mathrm{III})$ catalyst is not able to activate $\mathrm{C}-\mathrm{C} \pi$ bonds but simple $\mathrm{AlX}_{2}^{+}$ions were found potent in some cases.
\end{abstract}

Jiaxin Tian, ${ }^{[\mathrm{a}]}$ Yan Chen, ${ }^{[\mathrm{a}]}$ Marie Vayer, ${ }^{[\mathrm{a}]}$ Alexandre Djurovic, ${ }^{[\mathrm{a}]}$ Régis Guillot, ${ }^{[\mathrm{a}]}$ Refka Guermazi,${ }^{[\mathrm{b}]}$ Samuel Dagorne ${ }^{[b]}$ Christophe Bour, ${ }^{*[a]}$ and Vincent Gandon ${ }^{*[a, c]}$

\section{Introduction}

$\pi$-Acid catalysis, i.e. the electrophilic activation of C-C $\pi$ bonds with a Lewis acid, ${ }^{[1]}$ is a powerful way to transform alkyne, alkene or allene derivatives into valuable building blocks. Gold and platinum complexes have been the most versatile $\pi$-acids used so far. ${ }^{[2]}$ Other elements such as gallium and indium are also well-known in this field. ${ }^{[3]}$ In fact, not all $\pi$-activators behave the same way. Whereas a simple proton can promote the addition of water to alkynes through a vinyl cation intermediate, what makes gold, platinum, gallium and indium complexes rather unique is their capacity to mediate the addition of a C-C $\pi$ bond to another $\mathrm{C}-\mathrm{C} \pi$ bond through a nonclassical carbocation. ${ }^{[2],[4]}$ The cycloisomerization of enynes is a prototypical example of such a reactivity (Scheme 1, eq 1). [2a],[3c] The classification of Lewis acids between the softest ones, which will be good for mediating enyne cycloisomerizations, and harder ones, that will be more potent for C-C $\pi$ bond functionalization through classical carbocations, can be easily made by using the cycloheptatriene test that we developed. ${ }^{[5]}$ As described by Echavarren et al, 7-alkynylcycloheptatrienes are treated like enynes by gold $(\mathrm{I})$ complexes (Scheme 1 , eq (2)). ${ }^{[6]}$

[a] J. Tian, ${ }^{\dagger}$ Y. Chen, ${ }^{\dagger}$ Dr M. Vayer, Dr C. Bour, Prof. V. Gandon Institut de Chimie Moléculaire et des Matériaux d'Orsay (ICMMO), CNRS UMR 8182, Université Paris-Saclay, Bâtiment 420, 91405 Orsay cedex, France.

E-mail: vincent.gandon@universite-paris-saclay.fr

${ }^{\dagger}$ these authors contributed equally to this work

[b] Dr. S. Dagorne, Dr. R. Guermazi

Institut de Chimie de Strasbourg, CNRS-Université de Strasbourg, 1 rue Blaise Pascal, 67000 Strasbourg, France.

[c] Prof. V. Gandon

Laboratoire de Chimie Moléculaire (LCM), CNRS UMR 9168, Ecole Polytechnique, Institut Polytechnique de Paris, route de Saclay, 91128 Palaiseau cedex, France.

Supporting information for this article is given via a link at the end of the document.

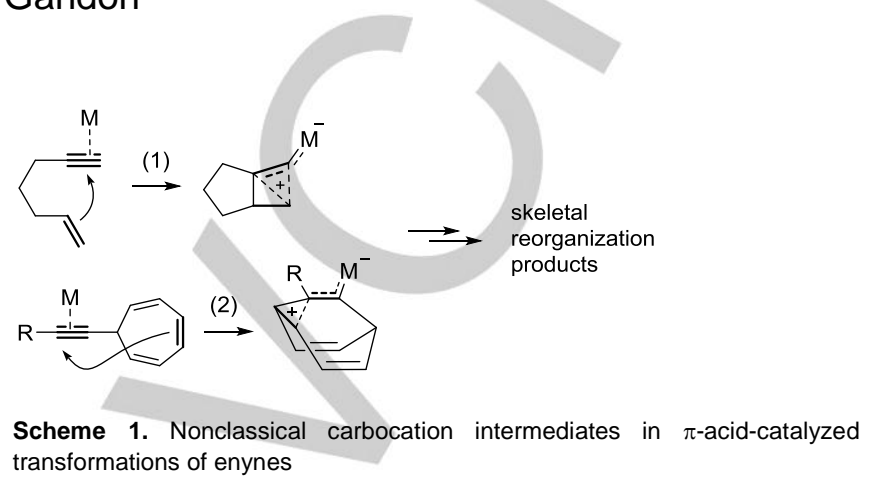

Likewise, we reported that the reaction of compound 1 with catalysts of the gold, platinum, mercury, gallium and indium series leads to its skeletal reorganization into the regioisomeric indenes 2 and $\mathbf{3}$ in 1,2-dichloroethane (DCE) or toluene (Scheme 2). With harder Lewis acids of the silver, gallium, copper, and calcium series, or even a Brønsted acid such as HOTf, the bicyclic product 4 is obtained. This occurs through the rearrangement of the 7-alkynylcycloheptatriene moiety into a phenylallene ${ }^{[7]}$ which undergoes a rapid hydroarylation by the pendant phenyl group. In DCE, a solvent that can give rise to superacids such as $\mathrm{HSbF}_{6}$ in the presence of $\mathrm{AgSbF}_{6}$ or $\mathrm{SbF}_{5},{ }^{[8],[9]}$ or by using $\mathrm{HNTf}_{2}$, the conversion of $\mathbf{4}$ into the tricyclic compound $\mathbf{5}$ is observed with time, which corresponds to the hydroarylation of the styrene moiety through a benzylic carbocation. $^{[5]}$

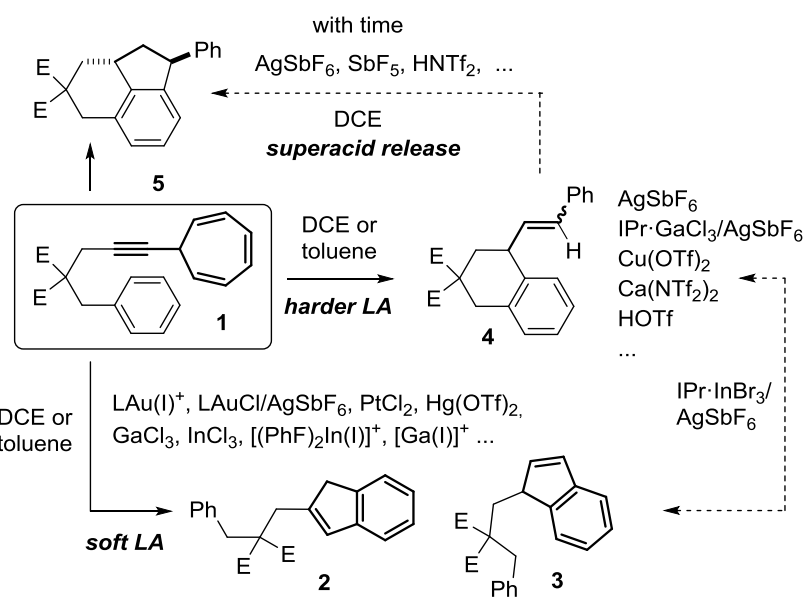

Scheme 2. Isomerization pathways of the 7-alkynylcycloheptatriene compound 1 ( $E=\mathrm{CO}_{2} \mathrm{Me} ; \mathrm{LA}=$ Lewis Acid; $\mathrm{DCE}=$ 1,2-dichloroethane) 
One interest of this test is to identify new soft $\pi$-acids, as we did in the gallium(I) and indium(I) series. ${ }^{[5],[10]}$ Another interest is to show the efficiency of an anion exchange. Indeed, since silver salts such as $\mathrm{AgSbF}_{6}$, which is a widely used halide abstractor, gives a different result than the softest Lewis acids (4 vs $2 / 3$ ), this test allows to validate the formation of the desired cationic species (such as IPr. $\operatorname{InBr}_{2}{ }^{+}$from IPr. $\mathrm{nnBr}_{3}$ and $\mathrm{AgSbF}_{6}$ ). Lastly, this test informs if the catalytic conditions release protons (5).

In this study, we have used the cycloheptatriene test and other reactions to analyze the catalytic behavior of other complexes of the main group metal series. We were especially interested in broadening the scope of application of $\pi$-acid catalysis to inexpensive metals such as zinc and aluminum. Regarding zinc, only simple salts of type $\mathrm{ZnX}_{2}$ have been used so far as $\pi$-acids. ${ }^{[11]}$ We have studied the case of the NHCstabilized zinc(II) species $\left[\mathrm{IPr} \cdot \mathrm{Zn}\left(\mathrm{C}_{6} \mathrm{~F}_{5}\right)\right]^{+}\left[\mathrm{B}\left(\mathrm{C}_{6} \mathrm{~F}_{5}\right)_{4}\right]^{-}$(Table 1, B) and $\mathrm{IPr} \cdot \mathrm{ZnBr}_{2}$ (THF) (Table 1, C). Synthesized by some of us, ${ }^{[12]}$ the aryl-zinc complex $\mathbf{B}$ has a higher fluoride ion affinity (FIA) than $\mathrm{B}\left(\mathrm{C}_{6} \mathrm{~F}_{5}\right)_{3}$ and efficiently catalyzes alkene, alkyne and $\mathrm{CO}_{2}$ hydrosilylation. Complex $\mathbf{C}$ has thus far not been reported but the related IMes. $\mathrm{ZnCl}_{2}(\mathrm{THF})$ is known ${ }^{[13]}$ and the $\mathrm{SIPr} / \mathrm{ZnBr}_{2}$ catalytic mixture has been used for the cycloaddition of $\mathrm{CO}_{2}$ to epoxides. ${ }^{[14]}$ Regarding aluminum complexes, we are not aware of their use as catalyst for cycloisomerization reactions. We have tested the $\mathrm{IMes} \mathrm{AlBr}_{3}$ complex $\mathbf{D}^{[15]}$ to allow direct comparison with C. Both new complexes C and D were characterized by $\mathrm{X}$-ray diffraction analyses. ${ }^{[16]}$

\section{Results and Discussion}

As mentioned above, 7-alkynylcycloheptatrienes rearrange into indenes under gold catalysis. ${ }^{[6]}$ So did compound $1^{[5]}$ when treated for instance by the cationic gold complex $\mathbf{A}$ (Table 1, 3 mol\%), displaying a IPr NHC ligand, in DCE at $80{ }^{\circ} \mathrm{C}$ for $20 \mathrm{~h}$ (Table 1, entry 1). A 58/42 mixture of indenes 2 and 3 has been isolated in $72 \%$ overall yield. The cationic IPr-stabilized aryl zinc complex B was then tested (entry 2). To our delight, under similar conditions, indene 2 was isolated as a sole product in $88 \%$ yield. The same result was obtained in toluene (entry 3 ). A better yield of $92 \%$ was reached when using $10 \mathrm{~mol} \%$ of catalyst (entry 4). The IPr substituted zinc bromide complex C proved unreactive (entry 5). However, a catalytic mixture of $\mathbf{C}$ and $\mathrm{AgSbF}_{6}$ (10 mol\% each), provided a 93/7 mixture of 2 and $\mathbf{3}$, isolated in $62 \%$ yield (entry 6). This is clearly not $\mathrm{AgSbF}_{6}$ that is responsible for this reaction since when used alone, $\mathrm{AgSbF}_{6}$ leads to a different product type (Scheme 2, compound 4) ${ }^{[5]}$ Even though it could not be isolated, this clearly supports the formation of $[\mathrm{IPr} \cdot \mathrm{ZnBr}]^{+}\left[\mathrm{SbF}_{6}\right]$ as active species. The same transformation could not be carried out in toluene lack of solubility of the catalyst ?(entry 6). Nevertheless, the involvement of protons cannot be invoked in DCE since neither 4 nor 5 (Scheme 2) were detected. Importantly, these NHCstabilized species $\mathbf{B}$ and $\mathbf{C}$ proved much more efficient than the simple zinc salts $\mathrm{ZnCl}_{2}, \mathrm{ZnBr}_{2}, \mathrm{Znl}_{2}$ and $\mathrm{Zn}(\mathrm{OTf})_{2}$ (entries 8-13), with which low yields and regioselectivities were at best obtained with $\mathrm{ZnBr}_{2}$ or $\mathrm{ZnI}_{2}$ in DCE (entries 9 and 10). It is also worthy of note that the activation of $\mathrm{ZnBr}_{2}$ as one of these zinc salts with $\mathrm{AgSbF}_{6}$ was not efficient, as it led to compound 4 (entry 14), i.e. the same as the one obtained in our previous study with $\mathrm{AgSbF}_{6}$ alone. ${ }^{[6 a]}$ No reaction took place with the aluminum complex $\mathbf{D}$ with or without $\mathrm{AgSbF}_{6}$, or $\mathrm{AlBr}_{3}$ alone (entries 15-20). As an indication of the formation of $\mathrm{HSbF}_{6}$ in $\mathrm{DCE}$, compounds $\mathbf{4}$ and $\mathbf{5}$ were isolated when using a mixture of $\mathrm{AlBr}_{3}$ and $\mathrm{AgSbF}_{6}$, whereas only 4 was produced in toluene (entries 21-22). entry 22 indicates the formation of a 9/1 4/5 mixture in toluene.

Table 1. Skeletal reorganization of 1.

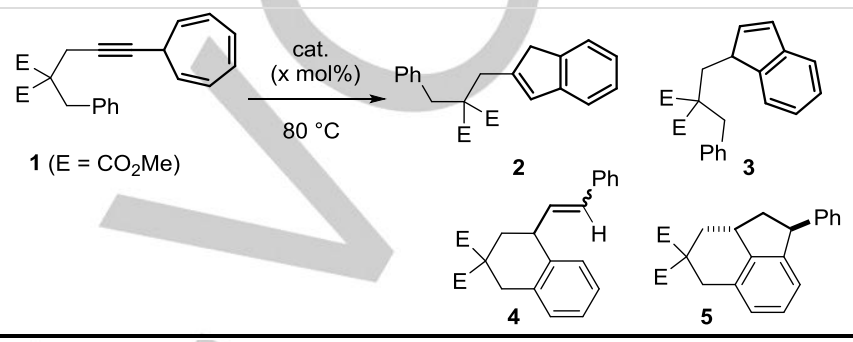

\begin{tabular}{|c|c|c|c|c|c|c|}
\hline Entry & cat. & $x$ & Solvent & $\begin{array}{l}\text { Time } \\
{[\mathrm{h}]}\end{array}$ & $2 / 3 / 4 / 5$ & $\begin{array}{l}\text { Yield } \\
{[\%]^{[a]}}\end{array}$ \\
\hline 1 & A & 3 & DCE & 20 & $58 / 42 / 0 / 0$ & 72 \\
\hline 2 & B & 3 & DCE & 24 & $100 / 0 / 0 / 0$ & 88 \\
\hline 3 & B & 3 & toluene & 24 & $100 / 0 / 0 / 0$ & 89 \\
\hline 4 & B & 10 & DCE & 24 & $100 / 0 / 0 / 0$ & 92 \\
\hline 5 & C & 10 & DCE & 24 & - & {$[$ [b] } \\
\hline 6 & $\mathbf{C} / \mathrm{AgSbF}_{6}$ & $10 / 10$ & DCE & 24 & $93 / 7 / 0 / 0$ & 62 \\
\hline 7 & $\mathbf{C} / \mathrm{AgSbF}_{6}$ & $10 / 10$ & toluene & 24 & - & $-[c]$ \\
\hline 8 & $\mathrm{ZnCl}_{2}$ & 10 & DCE & 24 & - & {$[\mathrm{b}]$} \\
\hline 9 & $\mathrm{ZnBr}_{2}$ & 10 & DCE & 24 & $86 / 14 / 0 / 0$ & 33 \\
\hline 10 & $\mathrm{ZnBr}_{2}$ & 10 & toluene & 24 & - & [c] \\
\hline 11 & $\mathrm{Znl}_{2}$ & 10 & DCE & 24 & $83 / 17 / 0 / 0$ & 34 \\
\hline 12 & $\mathrm{ZnI}_{2}$ & 10 & toluene & 24 & - & $-[c]$ \\
\hline 13 & $\mathrm{Zn}(\mathrm{OTf})_{2}$ & 10 & DCE & 24 & - & [d] \\
\hline 14 & $\mathrm{ZnBr}_{2} / \mathrm{AgSbF}_{6}$ & 10 & DCE & 24 & $0 / 0 / 100^{[\mathrm{e}]} / 0$ & 49 \\
\hline 15 & D & 20 & DCE & 24 & - & {$[\mathrm{b}]$} \\
\hline 16 & D & 20 & toluene & 24 & - & {$[b]$} \\
\hline 17 & $\mathrm{D} / \mathrm{AgSbF}_{6}$ & 20 & DCE & 24 & - & {$[\mathrm{b}]$} \\
\hline 18 & $\mathbf{D} / \mathrm{AgSbF}_{6}$ & 20 & toluene & 24 & - & {$[\mathrm{b}]$} \\
\hline 19 & $\mathrm{AlBr}_{3}$ & 20 & DCE & 24 & - & {$[\mathrm{b}]$} \\
\hline 20 & $\mathrm{AlBr}_{3}$ & 20 & toluene & 24 & - & {$[\mathrm{b}]$} \\
\hline 21 & $\mathrm{AlBr}_{3} / \mathrm{AgSbF}_{6}$ & 20 & DCE & 24 & $0 / 0 / 68^{[\mathrm{e}]} / 32$ & $66^{[f]}$ \\
\hline
\end{tabular}


The computed free energies corresponding to Scheme 3 are collected in Table 2. While the free energies of activation all [a] Isolated. [b] No reaction. [c] Very low conversion, trace of indene produseem reasonable, there is no kinetic preference for one indene detected. [d] Phenylallene observed, $20 \%$ yield. [e] 1:1 E/Z mixture. [f] Determined or the other in the gold series since TS $_{\mathrm{bc}}$ and $\mathbf{T S}_{\mathrm{be}}$ lie virtually at situ by ${ }^{1} \mathrm{H}$ NMR using $\mathrm{CH}_{2} \mathrm{Br}_{2}$ as internal standard.
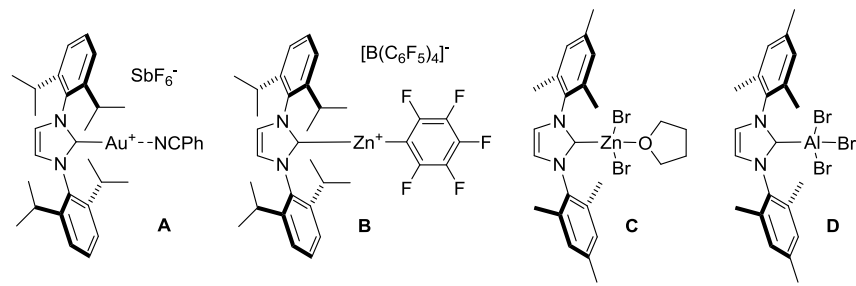

The mechanism of the indene formation promoted by the model gold and zinc NHC fragments shown in Scheme 3 was computed at the BP86/def2-QZVP(Au)- 6-311+G(2d,p)(other atoms)//BP86/LANL2DZ(Au,Zn)-6-31G(d,p)(other atoms). The 7alkynylcycloheptatriene complex a was used as starting compound. Based on these calculations, the formation of the indene scaffold of complex $\mathbf{g}$, corresponding to 2 in Table 1, can be explained as follows: the binding of the metal fragment to the triple bond triggers the nucleophilic attack of the middle double bond of the 1,3,5-triene fragment to give the cyclopropylcarbenoid $\mathbf{b}$. The latter rearranges into the bicyclic allyl cation e. A 1,2- $\mathrm{H}$ shift transforms $\mathbf{e}$ into the Wheland-type complex f. A 1,2-proton shift finally gives rise to the indene complex $\mathbf{g}$. For the formation of the other indene complex $\mathbf{d}$, corresponding to product 3 in Table 1 , the deciphered mechanism involves the rearrangement of $\mathbf{b}$ into the diallyl cation c, which undergoes a 1,2-methyl shift to give d (pink pathway).

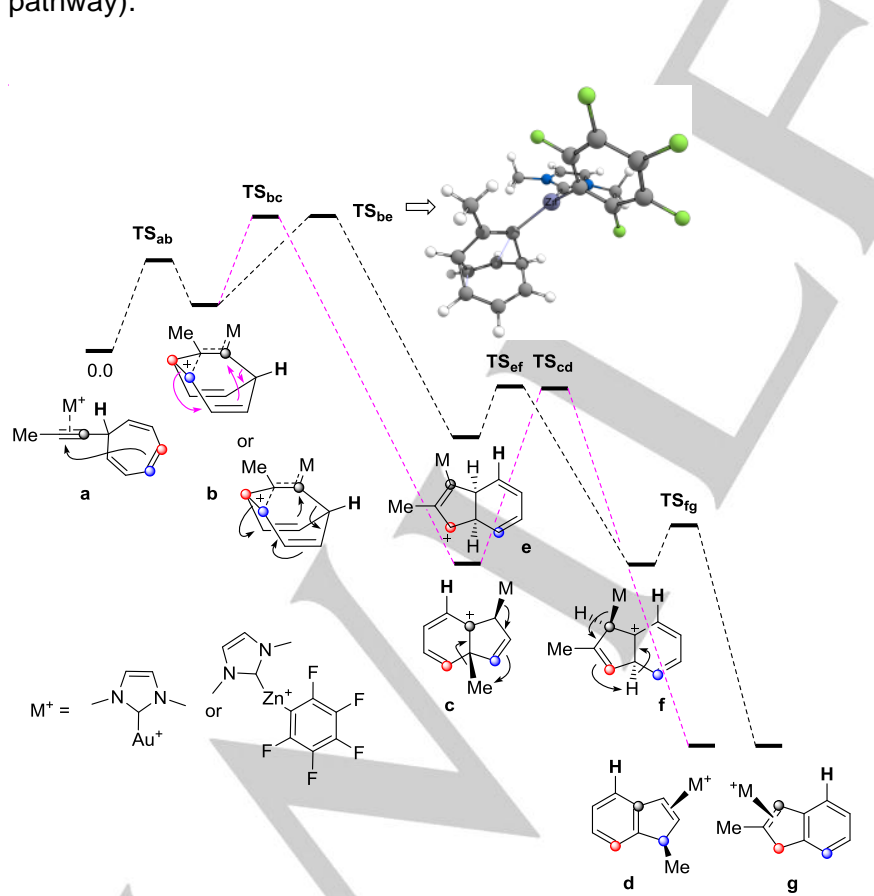

Scheme 3. Calculated intermediates and transition states for the formation of indenes from a 7-alkynylcycloheptatriene complex. the same value (14.0 and $14.3 \mathrm{kcal} / \mathrm{mol}$ respectively). Thus, a low selectivity is expected between the regioisomers, which is indeed the case between 2 and $\mathbf{3}$ when catalyst $\mathbf{A}$ is used (Table 1 , entry 1). On the other hand, in the zinc series, the values are markedly different: $18.1 \mathrm{kcal} / \mathrm{mol}$ for $\mathbf{T S}_{\mathrm{bc}}$ and $14.7 \mathrm{kcal} / \mathrm{mol}$ for TS $_{\text {be. }}$ A high regioselectivity in favor of the indene displaying the alkyl group at the $\beta$ position of the phenyl ring is therefore expected, which is corroborated by the selective formation of 2 (Table 1, entry 2).

Table 2. Computed free energies $\left(\Delta G_{298}, \mathrm{kcal} / \mathrm{mol}\right)$ relatively to a.

\begin{tabular}{|c|c|c|c|}
\hline Entry & $\begin{array}{l}\text { Computed } \\
\text { structure }\end{array}$ & Au series & Zn series \\
\hline 1 & $\mathbf{T S}_{\mathrm{ab}}$ & 11.8 & 10.6 \\
\hline 2 & b & 3.1 & 7.1 \\
\hline 3 & $\mathrm{TS}_{\mathrm{bc}}$ & 14.0 & 18.1 \\
\hline 4 & c & -19.6 & -25.4 \\
\hline 5 & $\mathbf{T S}_{\mathrm{cd}}$ & 0.8 & -23.6 \\
\hline 6 & d & -55.4 & -60.3 \\
\hline 7 & $\mathbf{T S}_{\mathrm{be}}$ & 14.3 & 14.7 \\
\hline 8 & e & -10.3 & -4.9 \\
\hline 9 & $\mathrm{TS}_{\text {ef }}$ & 1.2 & 5.9 \\
\hline 10 & $f$ & -28.8 & -34.8 \\
\hline 11 & $\mathbf{T S}_{\mathrm{fg}}$ & -23.1 & -29.6 \\
\hline 12 & $\mathbf{g}$ & -59.6 & -64.1 \\
\hline
\end{tabular}

Although the same kind of carbenoid intermediates are expected in the gold and zinc series, the zinc-derived ones seem less reactive towards double bonds. Echavarren et al reported that compound 6 transforms into tautomeric barbaralanes 7 and 8 when treated with the gold catalyst A (Scheme 4). They interconvert rapidly through a strain-assisted Cope rearrangement. ${ }^{[6]]}$ They likely arise from the trapping of the putative barbaralyl gold carbene. Using $\mathbf{B}$, the cyclopropanation was not observed, although the same barbaralyl carbene explains the formation of the indene isomers. Again, the $\mathbf{D} / \mathrm{AgSbF}_{6}$ mixture did not promote any reaction in this case. 


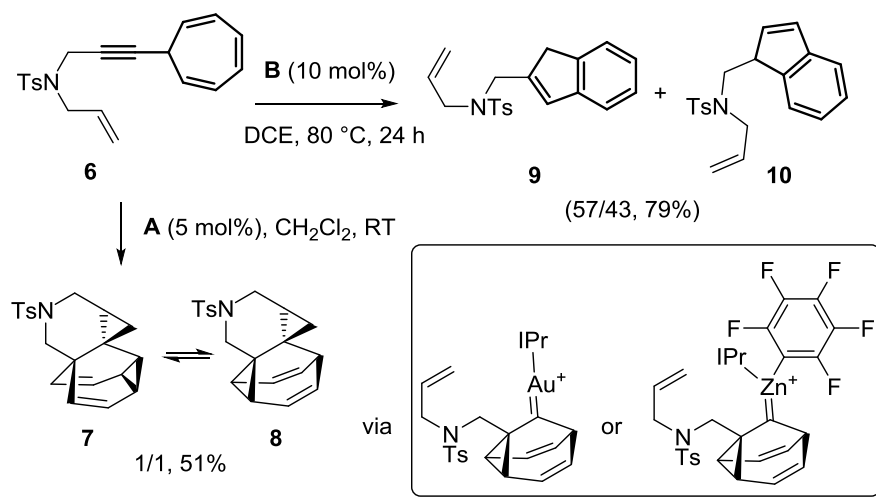

Scheme 4. Cycloisomerization of 6

This lack of reactivity could be due to the trigonal geometry around zinc (vs linear for gold), which brings the bulky $\mathrm{NHC}$ and the $\mathrm{C}_{6} \mathrm{~F}_{5}$ ligands closer to the carbene center. To validate this hypothesis, DFT computations were performed at the aforementioned level of theory (Scheme 5). The formation of the polycyclic scaffold of compounds 7 and 8 shown in Scheme 4 involves two main steps: formation of the cyclopropylcarbenoid $\mathbf{i}$ and the electrophilic cyclopropanation at the carbene center to give $\mathbf{j}$. While the first step is exergonic with gold, it remains, as found before, endergonic but attainable with zinc. There is yet a major difference between gold and zinc in the cyclopropanation step, the corresponding transition states lying at $13.4 \mathrm{kcal} / \mathrm{mol}$ and $20.6 \mathrm{kcal} / \mathrm{mol}$ respectively. We attribute this difference to the higher steric crowd around the zinc carbene center due to the trigonal geometry around the metal, vs a linear geometry with gold, which will place the bulky NHC further from the incoming double bond.
Scheme 5. Calculated key intermediates and transition states for the cycloisomerization of compound $6\left(\Delta G_{298}, \mathrm{kcal} / \mathrm{mol}\right)$.

Although the hydroarylation pathway to $\mathbf{4}$ (Scheme 2) was not observed with compound 1 under zinc catalysis (except Table 1 entry 14), such a reaction was independently tested using arenyne 11 (Table 3). This compounds was previously shown to undergo metal-catalyzed hydroarylation with $\mathrm{PtCl}_{2}$, $\left[\mathrm{RuCl}_{2}(\mathrm{CO})_{n} \mathrm{~L}_{\mathrm{m}}\right]_{2}$, $\quad\left[\mathrm{RuCl}_{2}(\mathrm{CO})_{\mathrm{n}} \mathrm{L}_{\mathrm{m}}\right]_{2} / \mathrm{AgOTf}$ and $\mathrm{GaCl}_{3}$. ${ }^{[17]}$ The reaction was very efficient with zinc, especially with the NHCstabilized species (entries 1 and 2). Of note, the hydroarylation catalyzed by $\mathrm{ZnBr}_{2}$ or $\mathrm{Znl}_{2}$ is more efficient than with $\mathrm{AlBr}_{3}$ (entries 3-4 vs 5), even though these simple salts could not compete with the NHC-complexes. Adding $\mathrm{AgSbF}_{6}(1 / 1 \mathrm{~mol} \%$ ratio) could enhance the activity of $\mathrm{ZnBr}_{2}$ (entries 3 vs 6), but not that of $\mathrm{Znl}_{2}$ and $\mathrm{AlBr}_{3}$ (entries 7 and 9 vs 4 and 5). The NHC-Al complex $\mathbf{D}$ left the starting material intact (entry 9). Since the reaction can be conducted in the presence of $\mathrm{AgSbF}_{6}$ alone with moderate efficiency (entry 10), we can postulate the formation of IMesAlBr${ }_{2}^{+}$ions which are yet inactive for this transformation.

Table 3. Hydroarylation of 11

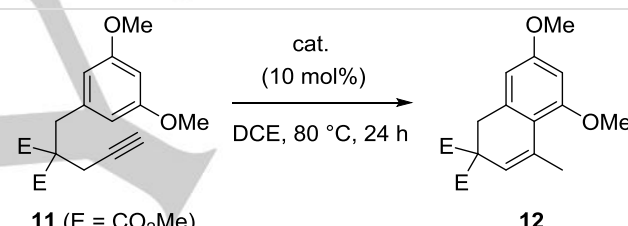

\begin{tabular}{lll}
\hline Entry & cat. & Yield [\%] $]^{[\mathrm{a}]}$ \\
\hline 1 & $\mathbf{B}$ & 95 \\
2 & $\mathbf{C} / \mathrm{AgSbF}_{6}$ & 96 \\
3 & $\mathrm{ZnBr}_{2}$ & 61 \\
4 & $\mathrm{ZnI}_{2}$ & 50 \\
5 & $\mathrm{AlBr}_{3}{ }^{[\mathrm{b}]}$ & 27 \\
7 & $\mathrm{ZnBr}_{2} / \mathrm{AgSbF}_{6}$ & 79 \\
8 & $\mathrm{ZnI}_{2} / \mathrm{AgSbF}_{6}$ & 50 \\
9 & ${\mathrm{D} / \mathrm{AgSbF}_{6}}_{10]}$ & 22 \\
10 & $\mathrm{AlBr}_{3} / \mathrm{AgSbF}_{6}$ & 55 \\
\hline
\end{tabular}

[a] Isolated. [b] 20 mol\%. [c] no reaction.

The transfer hydrogenation of alkenes using 1,4-cyclohexadiene derivatives as $\mathrm{H}_{2}$ surrogate is a very convenient process that can be catalyzed by gallium ${ }^{[18]}$ or boron complexes. ${ }^{[19]}$ The use of zinc in this field seems to be undocumented. ${ }^{[20]}$ The reduction of compound 13 (Table 4) was previously studied with the NHCgallium complex $\left[\mathrm{IPr} \cdot \mathrm{GaCl}_{2}\right]^{+}\left[\mathrm{SbF}_{6}\right]^{-}$, leading to the reduced product 14 in $67 \%$ yield. ${ }^{[18]}$ Here, also we observed an increased 
efficiency with the zinc catalyst $B$, which provided 14 in $80 \%$ yield (entry 1). Catalyst $\mathbf{C}, \mathrm{ZnBr}_{2}$ and $\mathrm{Znl}_{2}$ with $\mathrm{AgSbF}_{6}$ worked, but the yields did not exceed $68 \%$ (entries 2,5 , and 6 ). It is striking to note that no reaction took place with $\mathrm{ZnBr}_{2}$ or $\mathrm{Znl}_{2}$ alone (entries 3 and 4 ) or with the aluminum species used with $\mathrm{AgSbF}_{6}$ (entries 7 and 8). The NHC-zinc complexes also proved much more potent than the corresponding gold complex (entry 9).

Table 4. Transfer hydrogenation of $\mathbf{1 3}$

\begin{tabular}{lll}
$(1.2$ equiv $)$ \\
cat. \\
\hline $10 \mathrm{~mol} \%)$ \\
3
\end{tabular}

[a] Isolated. [b] No reaction. [c] 20 mol\% each.

We next turned our attention to the formation of C-O bonds. Compound 15 is an interesting substrate for the evaluation of $\pi$ acids (Table 5). As shown by Michelet, Genêt et al, with $\mathrm{AuCl}$ or $\mathrm{AuCl}_{3}$ as catalysts, the two alcohol functionalities react with the alkyne moiety to furnish the bicyclic ketal $16 .{ }^{[21]}$ A distinct behavior was reported by us when $\mathrm{GaCl}_{3}$ was used as catalyst, as only one hydroalkoxylation took place, giving rise to a cyclic enol. ${ }^{[3 \mathrm{~d}]}$ With the zinc species, similarly to gold, only product $\mathbf{1 6}$ was observed. It is complex $\mathbf{C}$ and $\mathrm{AgSbF}_{6}$ that gave the best result (84\% yield, entry 2). $\mathrm{ZnBr}_{2}$ and $\mathrm{Znl}_{2}$ were rather deactivated this time by the presence of the silver additive (entries $3 / 4$ vs $5 / 6$ ). The latter had little influence on the activity of $\mathbf{D}$ or $\mathrm{AlBr}_{3}$, which remained not sufficiently carbophilic to efficiently activate the alkyne functionality (entries 7 and 8). These hydroalkoxylations could well be catalyzed by an unsuspected Brønsted acid, but as mentioned above, the cycloheptatriene test has not detected the release of protons. Accordingly, it is important to note that the use of 2.2 equiv of 2,6-di-tert-butylpyridine had no effect on the reaction outcome. It is again, for entry 2 , likely that $[\mathrm{IPr} \cdot \mathrm{ZnBr}]^{+}\left[\mathrm{SbF}_{6}\right]^{-}$cette espèce peut elle être générée in situ et caractérisée par RMN ? is the active species. We can also infer that the $\mathrm{OH}$ groups in $\mathbf{1 5}$ can be acidic enough to promote the cleavage of the $\mathrm{Zn}-\mathrm{C}$ bond in $\mathbf{B}$, yielding a less reactive zinc alkoxyde, hence the low yield in entry 1 . In that respect, the zinc species used in this study do not tolerate the presence of water and therefore do not efficiently catalyze the hydration of $p$-methyl phenylacetylene, which is a major difference with gold catalysts. ${ }^{[22]}$

Table 5. Hydroalkoxylation of 15.

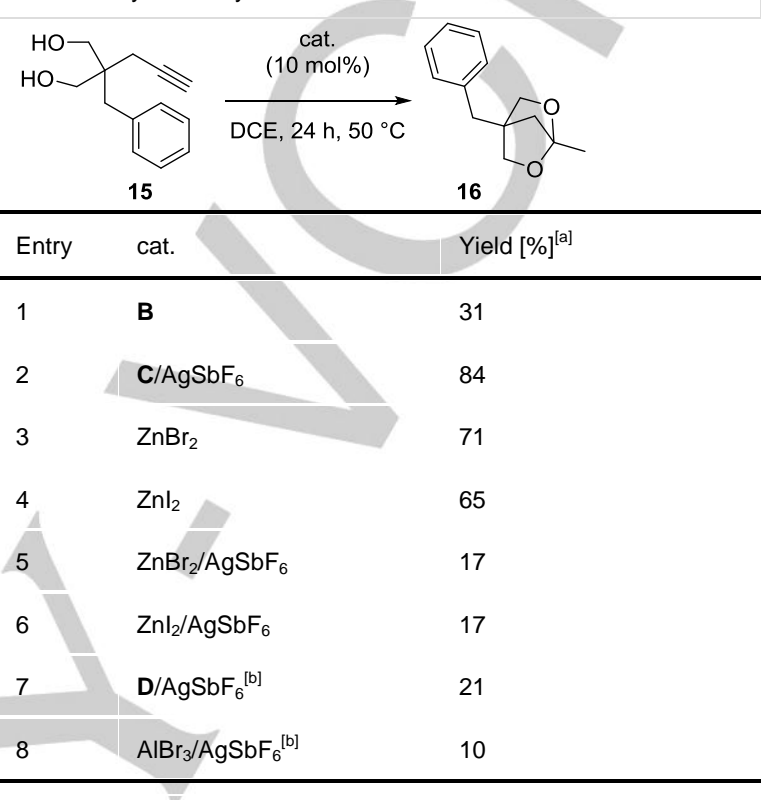

[a] Isolated. [b] 20 mol\% each.

The preferred behavior of the zinc species as soft $\pi$-Lewis acids rather than hard $\sigma$-Lewis acids ${ }^{[1 a]}$ was further confirmed using the $\beta$-ketoester 17a (Table 6). It is known to undergo carbonylolefin metathesis by $\sigma$-Lewis acid activation of the carbonyl group. ${ }^{[23]}$ Schindler et al have shown that $\mathrm{FeCl}_{3}{ }^{[24]}$ and $\mathrm{GaCl}_{3}{ }^{[25]}$ are particularly efficient mediators of such transformations, including that of $\mathbf{1 7 a}$. However, catalysts $\mathbf{B}, \mathbf{C} / \mathrm{AgSbF}_{6}, \mathrm{ZnBr}_{2}$ and $\mathrm{Znl}_{2}$ proved unable to trigger the metathesis (entries 1-4). Only harder $\mathrm{ZnX}^{+}$ions formed by halide abstraction with $\mathrm{AgSbF}_{6}$ provided the cyclic isomers 18 and 19 in good yields (entries 5 and 6). In the other hand, the reaction was over in $4 \mathrm{~h}$ at $50^{\circ} \mathrm{C}$ with the putative $\mathrm{AlBr}_{2}{ }^{+}$ion generated in situ, and the isolated yield was in the same range (entry 8 ). Schindler and coworkers recently reported a preprint describing an aluminum-based heterobimetallic ion pair as catalyst to promote carbonyl-olefin ring-closing metathesis. ${ }^{[26]}$

Table 6. Carbonyl-Olefin Metathesis of 17a

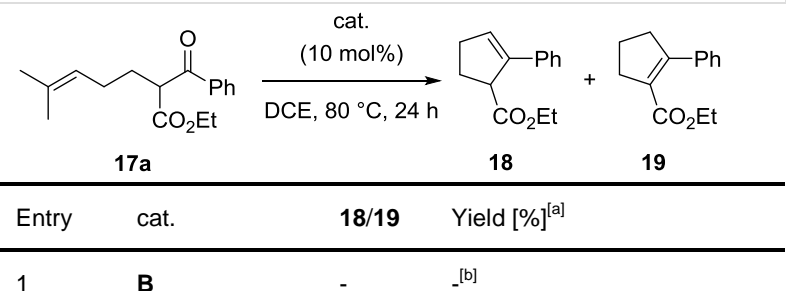




$\begin{array}{llll}2 & \mathrm{C}^{2} \mathrm{AgSbF}_{6} & - & { }_{-[\mathrm{b}]} \\ 3 & \mathrm{ZnBr}_{2} & - & -{ }^{[\mathrm{b}]} \\ 4 & \mathrm{Znl}_{2} & - & { }^{[\mathrm{b}]} \\ 5 & \mathrm{ZnBr}_{2} / \mathrm{AgSbF}_{6} & 58 / 42 & 90 \\ 6 & \mathrm{Znl}_{2} / \mathrm{AgSbF}_{6} & 82 / 18 & 84 \\ 7 & {\mathrm{D} / \mathrm{AgSbF}_{6}{ }^{[\mathrm{cc}]}} & - & -[\mathrm{d}] \\ 8 & \mathrm{AlBr}_{3} / \mathrm{AgSbF}_{6}{ }^{[\mathrm{c}]} & 67 / 33 & 79\end{array}$

[a] Isolated. [b] No reaction. [c] reaction performed with $20 \mathrm{~mol} \%$ of $\mathrm{AlBr}_{3} / \mathrm{AgSbF}_{6}$ at $50^{\circ} \mathrm{C}$ in $4 \mathrm{~h}$. [d] no reaction.

The tandem carbonyl-olefin/transfer hydrogenation of 17 was then attempted with 1,4-cyclohexadiene (1,4-CHD) as hydrogen donor (Table 7). This tandem process was recently reported by us using $\mathrm{IPr} \cdot \mathrm{GaCl}_{2}{ }^{+}$ions as catalyst. ${ }^{[27]}$ In this reaction, $\mathbf{1 7}$ is first transformed into cyclopentenes (such as 18/19), which then undergo transfer hydrogenation to cyclopentanes 20 . Thus, $\sigma-$ activation of the carbonyl is required in the first step, and then a $\pi$-activation of the $\mathrm{C}=\mathrm{C}$ bond is required in the second one. While zinc remained inefficient (entry 1 ), aluminum salts proved active. After screening the time and the equivalents of 1,4-CHD, we found that the reductive cyclization of $17 \mathrm{a}$, could be carried out in the presence of in situ generated $\mathrm{AlBr}_{2}{ }^{+}$ions (entries 2 and $3,82 \%$ yield for the optimized condition). With $\mathrm{Ar}=p$-fluoroand $p$-chloro-benzene, the aluminum-catalyzed reaction in DCE proved to be more efficient when compared to the galliumcatalyzed one; the ethyl 2-arylcyclopentane-carboxylates 20b-c were isolated in $44 \%$ and $60 \%$ yield respectively (entries $4-5$ ), vs $23 \%$ and $50 \%$ respectively in our previous study. ${ }^{[27]}$ These good results contrast with those shown in Table 4, but cyclic alkenes are usually more reactive.

Table 7. Hydrogenative carbonyle-ene metathesis of 17.

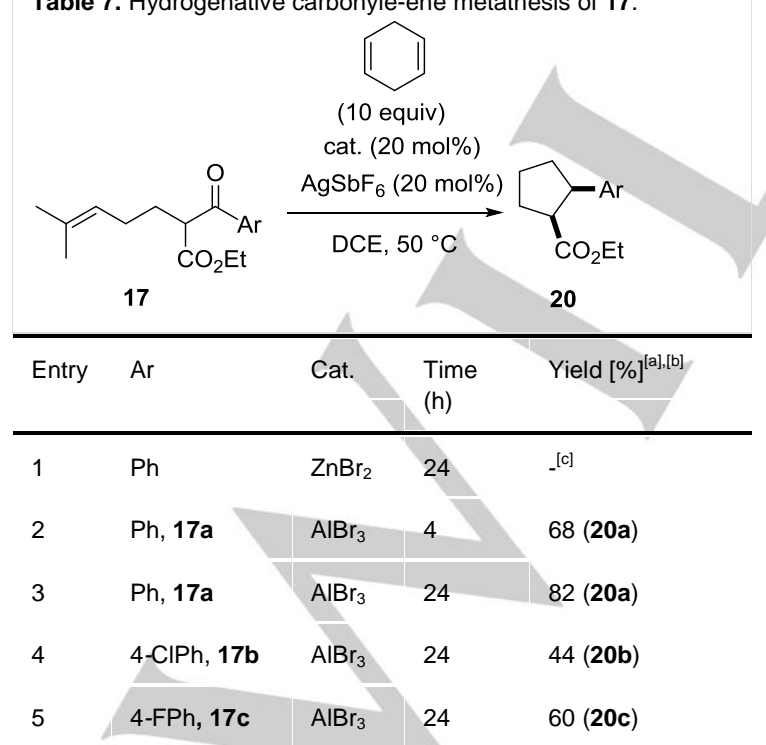

[a] Isolated. [b] cis/trans $d r>4 / 1$. [c] complex mixture.

\section{Conclusions}

Starting from the cycloheptatrienyl test, we have revealed that cationic NHC-Zn(II) complexes can be exquisite $\pi$-acids in various reactions such as skeletal rearrangements, hydroarylations, hydroalkoxylations and transfer hydrogenations. They can even compete with $\mathrm{NHC}-\mathrm{Au}(\mathrm{I})$ or $\mathrm{NHC}-\mathrm{Ga}$ (III) catalysts sometimes, although this study has delineated some of their limitations compared to gold and gallium species. This work also shows that NHC-stabilized zinc ions are more active than simple zinc halides. Due to its proximity with zinc and gallium in the periodic table, aluminum was also tested. This time, simple $\mathrm{AlX}_{2}{ }^{+}$ ions proved more active than a $\mathrm{NHC}-\mathrm{Al}(\mathrm{III})^{+}$species. They are much less versatile than the zinc complexes but have shown a promising activity in a tandem process at the border between $\pi$ and $\sigma$-Lewis acid catalysis.

\section{Experimental Section}

\section{Experimental Details.}

\section{Acknowledgements}

We are grateful to the China Scholarship Council (CSC, PhD grants for JT and YC), CNRS, MESRI (PhD grant for MV), Université Paris-Sud, ANR ANR-18-CE07-0033-01 (HICAT) and Ecole Polytechnique for their support of this work. We are thankful to the Umicore Company for a generous gift of metal complexes.

Keywords: Zinc • Aluminum • NHC ligand • Alkynes • Cycloisomerization $\cdot$ Carbonyl-ene metathesis

[1] a) Y. Yamamoto, J. Org. Chem. 2007, 72, 7817; b) D. J. Gorin, F. D. Toste, Nature 2007, 446, 395-403.

[2] a) A. Fürstner, P. W. Davies, Angew. Chem. Int. Ed. 2007, 46, 3410; b) A. S. K. Hashmi, Chem. Rev. 2007, 107, 3180-3211; c) Z. Li, C. Brouwer,C. He Chem. Rev. 2008, 108, 3239-3265; d) A. Fürstner, Chem. Soc. Rev. 2009, 38, 3208-3221; e) N. Shapiro, F. D. Toste, Synlett 2010, 675-691; f) S. P. Nolan, Acc. Chem. Res. 2011, 44, 91 100. g) C. Obradors, A. M. Echavarren, Acc. Chem. Res. 2014, 47, 902-912; h) L. Fensterbank, M. Malacria, Acc. Chem. Res. 2014, 47, 953-965; i) R. Dorel, A. M. Echavarren, Chem. Rev. 2015, 115, 90289072; j) D. Pflästerer, A. S. K. Hashmi, Chem. Soc. Rev. 2016, 45, 1331-1367; k) A. M. Echavarren, M. Muratore; V. López-Carrillo, A. Escribano-Cuesta, N. Huguet, C. Obradors, Org. React. 2017, 92, 1.

[3] a) N. Chatani, H. Inoue, T. Kotsuma, S. Murai, J. Am. Chem. Soc. 2002, 124, 10294-10295; b) Y. Miyanahana, N. Chatani, Org. Lett. 2006, 8, 2155-2158; c) V. Michelet, P. Y. Toullec, J.-P. Genêt, Angew. Chem. Int. 
Ed. 2008, 47, 4268-4315; d) H.-J. Li, R. Guillot, V. Gandon, J. Org. Chem. 2010, 75, 8435-8449; e) S. Tang, J. Monot, A. El-Hellani, B. Michelet, R. Guillot, C. Bour, V. Gandon, Chem. Eur. J. 2012, 18, 10239-10243; f) K. Surendra, E. J. Corey, J. Am. Chem. Soc. 2014, 136, 10918-10920; g) C. Bour, V. Gandon, Coord. Chem. Rev. 2014, 279, 43-57; h) C. Bour, V. Gandon, Synlett 2015, 26, 1427-1436; i) B. Michelet, G. Thiery, C. Bour, V. Gandon, J. Org. Chem. 2015, 80, 10925-10938; j) B. Michelet, S. Tang, G. Thiery, J. Monot, H. Li, R. Guillot, C. Bour, V. Gandon, V. Org. Chem. Front. 2016, 3, 1603-1613; k) J. Pérez Sestelo, L. A. Sarandeses, M. Montserrat Martínez, L. Alonso-Marañón, Org. Biomol. Chem. 2018, 16, 5733-5747.

[4] a) R. Dorel, A. M. Echavarren, J. Org. Chem. 2015, 80, 7321-7332; b) Y. Wang, M. E. Muratore, A. M. Echavarren, Chem. Eur. J. 2015, 21, 7332-7339.

[5] M. Vayer, R. Guillot, C. Bour, V. Gandon, Chem. Eur. J. 2017, 23, 13901-13905.

[6] a) P. R. McGonigal, C. de León, Y. Wang, A. Homs, C. R. SolorioAlvarado, A. M. Echavarren, Angew. Chem. Int. Ed. 2012, 51, 1309313096; b) S. Ferrer, A. M. Echavarren, Organometallics 2018, 37, 781 786; c) M. Mato, C. García-Morales, A. M. Echavarren, ChemCatChem 2019, 11, 53-72.

[7] S. Minegishi, J. Kamada, K. Takeuchi, K. Komatsu, T. Kitagawa, Eur. J. Org. Chem. 2003, 3497-3504.

[8] C. Bour, R. Guillot, V. Gandon, Chem. Eur. J. 2015, 21, 6066-6069.

[9] For the formation of HOTf from AgOTf in DCE, see: T. T. Dang, F. Boeck, L. Hintermann, J. Org. Chem. 2011, 76, 9353-9361.

[10] Z. Li, G. Thiery, M. Lichtenthaler, R. Guillot, I. Krossing, V. Gandon, C. Bour, Adv. Synth. Catal. 2018, 360, 544-549.

[11] For selected examples, see: a) M.-Y. Lin, A. Das, R.-S. Liu, J. Am. Chem. Soc. 2006, 128, 9340-9341; b) R. Vicente, J. González, L. Riesgo, J. González, L. A. López, Angew. Chem. Int. Ed. 2012, 51 8063-8067; c) J. González, L. A. López, R. Vicente, Chem. Commun 2014, 50, 8536-8538; d) M. J. González, L. A. López, R. Vicente, Tetrahedron Lett. 2015, 56, 1600-1608; e) B. Wang, Y. Chen, L. Zhou, J. Wang, C.-H. Tung, Z. Xu, J. Org. Chem. 2015, 80, 12718-12724; f) L. Li, B. Zhou, Y.-H. Wang, C. Shu, Y.-F. Pan, X. Lu, L.-W. Ye, Angew. Chem. Int. Ed. 2015, 54, 8245-8249; g) B. Wang, Y. Chen, L. Zhou, J. Wang Z. Xu, Org. Biomol. Chem. 2016, 14, 826-829; h) S. Yorimoto, A. Tsubouchi, H. Mizoguchi, H. Oikawa, Y. Tsunekawa, T. Ichino, S. Maeda, H. Oguri, Chem. Sci., 2019, 10, 5686-5698.

[12] D. Specklin, F. Hild, C. Fliedel, C. Gourlaouen, L. F. Veiros, S. Dagorne, Chem. Eur. J. 2017, 23, 15908-15912.
[13] Adapted from a) D. Wang, K. Wurst, M. R. Buchmeiser, J. Organometal. Chem. 2004, 689, 2123-2130; b) A. Rit, A.-K. Wiegand, D. Mukherjee, T. P. Spaniol, J. Okuda, Eur. J. Inorg. Chem. 2018, 1114-1119.

[14] X Liu, C. Cao, Y. Li, P. Guan, L. Yang, Y. Shi, Synlett 2012, 23, 13431348.

[15] Adapted from B. Bantu, G. M. Pawar, K. Wurst, U. Decker, A. M. Schmidt, M. R. Buchmeiser, Eur. J. Inorg. Chem. 2009, 1970-1976.

[16] CCDC 1977549-1977550 contains the supplementary crystallographic data for this paper.

[17] a) N. Chatani, H. Inoue, T. Ikeda, S. Murai, J. Org. Chem. 2000, 65, 4913-4918; b) H. Inoue, N. Chatani, S. Murai, J. Org. Chem. 2002, 67, 1414-1417; c) L. V. Graux, M. Giorgi, G. Buono, H. Clavier, Organometallics 2015, 34, 1864-1871.

[18] B. Michelet, C. Bour, V. Gandon, Chem. Eur. J. 2014, 20, 14488-14492.

[19] I. Chatterjee, Z.-W. Qu, S. Grimme, M. Oestreich, Angew. Chem. Int. Ed. 2015, 54, 12158.492.

[20] D. Wang, D. Astruc, Chem. Rev. 2015, 115, 6621-6686.

[21] S. Antoniotti, E. Genin, V. Michelet, J.-P. Genêt, J. Am. Chem. Soc. 2005, 127, 9976-9977.

[22] a) J. H. Teles, S. Brode, M. Chabanas, Angew. Chem. Int. Ed. 1998, 37, 1415-1418; b) G. A. Fernández, A. B. Chopa, G. F. Silbestri, Catal. Sci. Technol. 2016, 6, 1921-1929.

[23] L. Ravindar, R. Lekkala, K. P. Rakesh, A. M. Asiri, H. M. Marwani, H.-L. Qin, Org. Chem. Front. 2018, 5, 1381-1391.

[24] a) J. R. Ludwig, P. M. Zimmerman, J. B. Gianino, C. S. Schindler, Nature, 2016, 533, 374-379; b) L. Ma, W. Li, H. Xi, X. Bai, E. Ma, X. Yan, Z. Li, Angew. Chem., Int. Ed. 2016, 55, 10410-10413; c) C. C. McAtee, P. S. Riehl, C. S. Schindler, J. Am. Chem. Soc. 2017, 139, 2960-2963; d) J. R. Ludwig, S. Phan, C. C. McAtee, P. M. Zimmerman, J. J. Devery, C. S. Schindler, J. Am. Chem. Soc. 2017, 139, 1083210842; h) H. Albright, P. S. Riehl, C. C. McAtee, J. P. Reid, J. R. Ludwig, L. A. Karp, P. M. Zimmerman, M. S. Sigman, C. S, Schindler, J. Am. Chem. Soc. 2019, 141, 1690-1700.

[25] H. Albright, H. L. Vonesh, M. R. Becker, B. W. Alexander, J. R. Ludwig, R. A. Wiscons, C. S. Schindler, Org. Lett. 2018, 20, 4954-4958.

[26] R. B. Watson, A. J. Davis, D. J. Nasrallah, J. L. Gomez-Lopez, C. S. Schindler, ChemRxiv. Preprint. https://doi.org/10.26434/chemrxiv. 9911783.v1.

[27] For gallium-catalyzed tandem carbonyl-olefin metathesis/transfer hydrogenation, see: A. Djurovic, M. Vayer, Z. Li, R. Guillot, J.-P. Baltaze, V. Gandon, C. Bour, Org. Lett. 2019, 21, 8132-8137. 
Entry for the Table of Contents (Please choose one layout)

Layout 1:

\section{FULL PAPER}

Text for Table of Contents

Layout 2:

\section{FULL PAPER}

Graphic here: $\max$ width: $5.5 \mathrm{~cm}$; max. height: $5.0 \mathrm{~cm}$ ))

Author(s), Corresponding Author(s)*

Page No. - Page No.

Title
((Insert TOC Graphic here; max. width: $11.5 \mathrm{~cm}$; max. height: $2.5 \mathrm{~cm})$ )
Author(s), Corresponding Author(s)*

Page No. - Page No.

Title 